\title{
Progressive Outer Retinal Necrosis and Immunosuppressive Therapy in Myasthenia Gravis
}

\author{
Solène Coisy ${ }^{\mathrm{a}}$ Jean-Marc Ebran ${ }^{\mathrm{a}} \quad$ Dan Milea $^{\mathrm{a}} \mathrm{b}$ \\ ${ }^{a}$ Service d'Ophtalmologie, Centre Hospitalier Universitaire d'Angers, Université d'Angers,

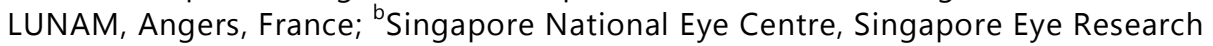 \\ Institute and Duke-NUS, Singapore, Singapore
}

\section{Key Words}

Retinitis · Progressive outer retinal necrosis · Varicella zoster retinitis

\begin{abstract}
Introduction: Progressive outer retinal necrosis (PORN) is a rare but devastating infectious retinitis associated with varicella zoster virus (VZV) and responsible for severe visual loss. Case Report: A 59-year-old man treated for generalized myasthenia with oral azathioprine and prednisone presented with severe unilateral necrotizing retinitis. Polymerase chain reaction of the aqueous and vitreous humors was diagnostic for VZV PORN. Conclusion: VZV PORN is a severe potential ocular complication of immunosuppression, prompting urgent diagnosis and appropriate treatment.

(C) 2014 S. Karger AG, Basel
\end{abstract}

\section{Introduction}

Varicella zoster virus (VZV) progressive outer retinal necrosis (PORN) is a devastating ocular complication responsible for severe visual loss, occurring almost exclusively in patients with AIDS. Affected patients complain of blurring vision or vague visual loss (54\%), constriction of the visual field or loss of peripheral vision (28\%), floaters (1\%), pain (6\%), or are asymptomatic (11\%) [1]. The fundoscopic examination is characterized by multifocal retinal opacities starting at the peripheral retina, involving the posterior pole in $30 \%$ of cases, being rapidly coalescent and progressing to complete retinal necrosis $[1,2]$. The retinitis tends to be bilateral with time ( $61 \%$ of patients), i.e. within 4 weeks in the study by Engstrom et al. [1]. Intraocular inflammation and vasculitis are usually absent, which differentiates PORN from VZV acute retinal necrosis affecting non-immunosuppressed 
Coisy et al.: Progressive Outer Retinal Necrosis and Immunosuppressive Therapy in Myasthenia Gravis

patients [3]. The diagnosis is based on isolating VZV DNA by polymerase chain reaction in the aqueous and/or vitreous humor [3]. Even if this affection was first described in a human immunodeficiency virus (HIV)-positive patient in 1990 by Forster et al. [4], a few cases have been reported in HIV-negative patients treated with immunosuppressive therapies.

Here we report a case of VZV PORN in a patient treated with immunosuppressive therapies for a generalized myasthenia.

\section{Case Report}

A 59-year-old man was admitted with unilateral progressive visual loss in the right eye occurring over the last 7 days and evolving to counting fingers. He had been diagnosed with generalized myasthenia 2 years earlier and during the last 20 months he had been treated with oral prednisone $(60 \mathrm{mg}$ /day at first for 4 weeks with subsequent tapering down to 20 $\mathrm{mg} /$ day, which was his regimen during 14 months). Oral azathioprine $(150 \mathrm{mg} /$ day $)$ was added 1 month prior to visual loss to treat complete ophthalmoplegia and ptosis in the left eye. The right eye's intraocular pressure was $18 \mathrm{~mm} \mathrm{Hg}$. There was no corneal opacity and no iris anomaly. Ophthalmic examination of the right eye disclosed no anterior chamber inflammation and no retinal vasculitis; however, mild vitritis, an optic disc edema and macular and peripheral necrotizing retinitis in the right eye (fig. 1, fig. 2). Visual acuity of the left eye was $20 / 20$, and the remainder of the ophthalmic examination was normal. Polymerase chain reaction of the aqueous and vitreous humors performed in the right eye was positive for VZV and negative for cytomegalovirus and herpes simplex virus 1 and 2 . The diagnosis was consistent with VZV PORN. HIV serology was negative, and the CD4 lymphocyte count $\left(1,389 / \mathrm{mm}^{3}\right)$ and CD4/CD8 ratio (1.74) were normal. Lumbar puncture and cerebral MRI found no signs of central nervous system zoster meningitis, encephalitis or vasculitis. Oral azathioprine therapy was discontinued, and steroid doses were progressively decreased. Two intravitreal injections of ganciclovir were followed by 10 intravitreal injections of foscarnet. High doses of intravenous foscarnet $(180 \mathrm{mg} / \mathrm{kg} / \mathrm{day})$ and acyclovir (30 mg/kg/day) were also administered. As acute renal failure occurred after 2 weeks, foscarnet was discontinued and half of the dose of acyclovir was given for one more week. The patient was then discharged on oral acyclovir ( $15 \mathrm{mg} / \mathrm{kg} /$ day) for 3 months. After 10 months of follow-up, his best vision was counting fingers in the right eye and 20/20 in the left eye. The patient had no other ocular complications such as retinal detachment.

\section{Discussion}

The main finding of this report is that VZV PORN can occur in a patient affected by another ophthalmic condition, i.e. ocular myasthenia gravis. The retinal symptoms could have been initially misleading, but the immunosuppressed status of the patient prompted the exploration of PORN in this non-HIV-infected patient. The patient's symptoms (painless rapidly progressive visual loss), the appearance of retinal lesions (multifocal, coalescent and peripheral), the lack of anterior and posterior inflammation, the lack of response to treatment and the presence of VZV in aqueous and vitreous humors without another herpes virus (cytomegalovirus, herpes simplex virus) were typical of PORN [1-4], in a context of immunosuppressive treatments recently introduced with azathioprine and prednisone. The context of recently introduced azathioprine associated with corticosteroids supports this diagnosis. It is well known that the use of azathioprine and/or steroids is associated with an 
Coisy et al.: Progressive Outer Retinal Necrosis and Immunosuppressive Therapy in Myasthenia Gravis

increased risk of herpes zoster, and that this association is stronger among new users than persistent users of these drugs $[5,6]$.

Indeed, this case is illustrative of a rare but serious complication of immunosuppressive therapy. To our knowledge, no other case of VZV PORN in a patient with another ophthalmic condition and/or with azathioprine has been reported. Only 10 other cases secondary to immunosuppressive therapies have been described (table 1) [6-17], but none secondary to azathioprine and none in a patient treated for myasthenia. The patients described in table 1 were treated for allogeneic stem cell transplants [7-10], idiopathic thrombocytopenic purpura [11], cutaneous non-Hodgkin's lymphoma [12], rheumatoid arthritis [13, 14], multiple sclerosis [13], nephrotic syndrome [15] and lymphocytic lymphoma [16]. Another case has been reported on a non-HIV patient with a transient decrease in CD4 lymphocyte count and CD4/CD8 ratio, who has been treated at first with prednisolone only (table 1) [17]. The reports on patients after stem cell transplantation were all bilateral and associated with disseminated cutaneous herpes zoster or local cutaneous VZV (table 1) [7-10]. The reports on patients with rheumatoid arthritis and on the one patient with idiopathic thrombocytopenic purpura were also bilateral $[11,13,14]$. PORN tends to be bilateral with time in HIV patient series (61-70\% of patients) [1,2], which was not the case in our patient. In addition, our patient could not report a previous or concurrent extraocular VZV manifestation, unlike $67-75 \%$ of patients in HIV patient series [1,2]. Unfortunately, no VZV PORN cases in non-HIV patient series are available, probably because they are too rare. No accurate data as in HIV patients is available to assess how often the retinitis is bilateral in these patients. However, a careful monitoring of the other eye seems essential to detect PORN and to treat it early.

The current recommendations for PORN include antiviral intravitreal injections 3 times a week for 2 weeks (ganciclovir or foscarnet), followed by injections once or twice a week until the retinitis is stabilized. High doses of intravenous antiviral double therapy (ganciclovir or valganciclovir at induction doses for 3 weeks and foscarnet at induction doses for 2 weeks) are required to protect the other eye and the central nervous system, followed by maintenance antiviral therapy (oral valganciclovir and intravenous foscarnet) until complete healing. Oral valganciclovir or valacyclovir can then be continued [18]. Our patient was treated twice a week with intravitreal antiviral injections and intravenous high doses of antivirals (foscarnet and acyclovir) during 2 weeks and with half of the doses of intravenous acyclovir for 1 additional week. The visual outcome in HIV-patients is poor: 67 and $49 \%$ of patients had a final visual acuity of 'no light perception' within 4 weeks and 6 months after the initial diagnosis, respectively $[1,2]$. The visual outcome may be better in patients treated with more than 1 intravenous antiviral agent, and even more so when using both intravenous and intravitreal antiviral agents [18]. In Scott et al.'s study, $45 \%$ of eyes treated with both intravitreal and intravenous antivirals had a final visual acuity of $20 / 80$ or better [18].

One of the aims of the treatment in our patient was to prevent the involvement of the left eye and to preserve the right eye from retinal detachment. Indeed, about $70 \%$ of eyes develop rhegmatogenous retinal detachment $[1,2]$ within a median time of 30 days to 3 months after presentation [3]. Without laser treatment, our patient did not develop retinal detachment after 10 months; indeed, prophylactic demarcating laser treatment is controversial in this setting $[3,18]$. 
Coisy et al.: Progressive Outer Retinal Necrosis and Immunosuppressive Therapy in Myasthenia Gravis

\section{Conclusion}

VZV PORN is a devastating ocular complication, typically occurring in severely immunosuppressed patients (in particular HIV patients) and characterized by multifocal peripheral and posterior retinal lesions which rapidly coalesce without anterior inflammation and vasculitis. In a patient with visual loss, while on longstanding immunosuppressive therapy, PORN is a rare albeit possible cause, beyond several common diagnoses (i.e. keratitis, uveitis, toxoplasmosis, syphilitic chorioretinitis), which needs prompt treatment. Thus, a careful examination of the peripheral retina is required for an early diagnosis. A delayed diagnosis may result in retinal necrosis and detachment, affecting both eyes and potentially leading to irreversible blindness. The treatment requires antiviral intravitreous injections and intravenous therapy.

\section{References}

1 Engstrom RE Jr, Holland GN, Margolis TP, Muccioli C, Lindley JI, Belfort R Jr, Holland SP, Johnston WH, Wolitz RA, Kreiger AE: The progressive outer retinal necrosis syndrome: a variant of necrotizing herpetic retinopathy in patients with AIDS. Ophthalmology 1994;101:1488-1502.

-2 Moorthy RS, Weinberg DV, Teich SA, Berger BB, Minturn JT, Kumar S, Rao NA, Fowell SM, Loose IA, Jampol LM: Management of varicella zoster virus retinitis in AIDS. Br J Ophthalmol 1997;81:189-194.

-3 Austin RB: Progressive outer retinal necrosis syndrome: a comprehensive review of its clinical presentation, relationship to immune system status, and management. Clin Eye Vis Care 2000;12:119-129.

-4 Forster DJ, Dugel PU, Frangieh GT, Liggett PE, Rao NA: Rapidly progressive outer retinal necrosis in the acquired immunodeficiency syndrome. Am J Ophthalmol 1990;110:341-348.

5 Kim MJ, Choe YH: Monitoring and safety of azathioprine therapy in inflammatory bowel disease. Pediatr Gastroenterol Hepatol Nutr 2013;16:65-70.

6 Gupta G, Lautenbach E, Lewis JD: Incidence and risk factors for herpes zoster among patients with inflammatory bowel disease. Clin Gastroenterol Hepatol 2006;4:1483-1490.

7 Gill H, Cheung J, Wong I, Lie AK, Kwong YL: Varicella zoster virus progressive outer retinal necrosis after allogeneic haematopoietic stem cell transplantation. Br J Haematol 2012;157:279.

-8 Kalpoe JS, van Dehn CE, Bollemeijer JG, Vaessen N, Claas EC, Barge RM, Willemze R, Kroes AC, Beersma MF: Varicella zoster virus (VZV)-related progressive outer retinal necrosis (PORN) after allogeneic stem cell transplantation. Bone Marrow Transplant 2005;36:467-469.

-9 Khot A, Dignan F, Taylor S, Potter M, Cubitt D, Treleaven JG: Another case of PORN (bilateral progressive outer retinal necrosis) after allogeneic stem cell transplantation. Bone Marrow Transplant 2006;37:113114.

10 Patel A, Olavarria E: Optic neuritis preceding progressive outer retinal necrosis in an immunocompromised patient after allogeneic stem cell transplantation. Ann Hematol 2013;92:1427-1429.

$\checkmark 11$ Doi M, Matsui K, Akamine T, Sasoh M, Uji Y, Taniguchi H: Progressive outer retinal necrosis in a human immunodeficiency virus-negative patient. Retina 1999;19:468-470.

12 Njoo FL, Rothova A, Van Der Lelij A: Progressive outer retinal necrosis in a patient with cutaneous nonHodgkin's T cell lymphoma (Sézary syndrome). Br J Ophthalmol 1998;82:1218-1219.

13 Benz MS, Glaser JS, Davis JL: Progressive outer retinal necrosis in immunocompetent patients treated initially for optic neuropathy with systemic corticosteroids. Am J Ophthalmol 2003;135:551-553.

$\checkmark 14$ Bryan RG, Myers FL: Progressive outer retinal necrosis in a patient with rheumatoid arthritis. Arch Ophthalmol 1998;116:1249.

15 Shinoda K, Inoue M, Ishida S, Kawashima S, Wakabayashi T, Suzuki S, Katsura H: Progressive outer retinal necrosis in a patient with nephrotic syndrome. Ophthalmic Surg Lasers 2001;32:67-72.

16 Foster RE, Petersen MR, Neuss MN, Osher RH: Progressive outer retinal necrosis syndrome in a lymphoma patient with good visual outcome. Am J Ophthalmol 2001;132:117-120.

17 Lim WK, Chee SP, Nussenblatt RB: Progression of varicella-zoster virus necrotizing retinopathy in an HIVnegative patient with transient immune deviation. Graefes Arch Clin Exp Ophthalmol 2005;243:607-609.

-18 Scott IU, Luu KM, Davis JL: Intravitreal antivirals in the management of patients with acquired immunodeficiency syndrome with progressive outer retinal necrosis. Arch Ophthalmol 2002;120:12191222. 


\begin{tabular}{l|l}
\hline DOI: $10.1159 / 000362662$ & $\begin{array}{l}\text { C 2014 S. Karger AG, Basel } \\
\text { www.karger.com/cop }\end{array}$ \\
\hline
\end{tabular}

Coisy et al.: Progressive Outer Retinal Necrosis and Immunosuppressive Therapy in Myasthenia Gravis

Table 1. Case reports of PORN in non-HIV patients treated with immunosuppressive therapies

\begin{tabular}{|c|c|c|c|c|c|}
\hline Ref. & $\begin{array}{l}\text { Cases, } \\
\mathrm{n}\end{array}$ & $\begin{array}{l}\text { Unilateral/ } \\
\text { bilateral }\end{array}$ & Diagnosis & Immunosuppressive therapy & PORN treatment \\
\hline [10] & 1 & Bilateral & Acute lymphoblastic leukemia & $\begin{array}{l}\text { Hematopoietic stem cell } \\
\text { transplantation and steroids }\end{array}$ & $\begin{array}{l}\text { Intravenous ganciclovir and foscarnet, } \\
\text { followed by intravenous cidofovir and } \\
\text { intravitreous foscarnet }\end{array}$ \\
\hline [7] & 1 & Bilateral & Acute myeloid leukemia & $\begin{array}{l}\text { Methylprednisolone, ciclosporin, } \\
\text { mycophenolate mofetil, } \\
\text { anti-thymocyte globulin for stem } \\
\text { cell transplantation }\end{array}$ & $\begin{array}{l}\text { Intravitreal ganciclovir and } \\
\text { intravenous high-dose acyclovir }\end{array}$ \\
\hline [9] & 1 & Bilateral & $\begin{array}{l}\text { Refractory anemia with excess } \\
\text { blasts type } 1\end{array}$ & $\begin{array}{l}\text { Ciclosporin, prednisolone, } \\
\text { mycophenolate mofetil after stem } \\
\text { cell transplantation }\end{array}$ & $\begin{array}{l}\text { Intravenous foscarnet, ganciclovir and } \\
\text { cidofovir, intravitreal foscarnet } \\
\text { injections and } 1 \text { dose of human } \\
\text { immunoglobulin }(0.4 \mathrm{~g} / \mathrm{kg})\end{array}$ \\
\hline [8] & 1 & Bilateral & T-lymphoblastic lymphoma & $\begin{array}{l}\text { Thiotepa, fludarabine and } \\
\text { anti-thymocyte globulin for stem } \\
\text { cell transplantation }\end{array}$ & Intravenous and intravitreal foscarnet \\
\hline [17] & 1 & Unilateral & Transient immune deviation & Prednisolone & $\begin{array}{l}\text { Intravitreal foscarnet injection, } \\
\text { intravenous acyclovir }\end{array}$ \\
\hline [13] & 2 & $\begin{array}{l}\text { Unilateral/ } \\
\text { bilateral }\end{array}$ & $\begin{array}{l}\text { Multiple sclerosis/ } \\
\text { rheumatoid arthritis }\end{array}$ & Steroids & $\begin{array}{l}\text { Intravenous acyclovir, intravitreal } \\
\text { injections of ganciclovir and foscarnet }\end{array}$ \\
\hline [16] & 1 & Unilateral & $\begin{array}{l}\text { Small lymphocytic } \\
\text { lymphoma }\end{array}$ & $\begin{array}{l}\text { Corticosteroids and alkylating } \\
\text { agent therapy (chlorambucil and } \\
\text { cyclophosphamide) }\end{array}$ & $\begin{array}{l}\text { Intravenous foscarnet and ganciclovir, } \\
\text { intravenous gammaglobulin } \\
\text { ( } 0.5 \mathrm{mg} / \mathrm{kg} / \text { day) for } 5 \text { days and oral } \\
\text { decadron ( } 16 \mathrm{mg} / \text { day) }\end{array}$ \\
\hline [15] & 1 & Unilateral & Nephrotic syndrome & Prednisolone & Intravenous high-dose acyclovir \\
\hline [11] & 1 & Bilateral & $\begin{array}{l}\text { Idiopathic thrombocytopenic } \\
\text { purpura }\end{array}$ & $\begin{array}{l}\text { Methylprednisolone, } \\
\text { gammaglobulin, vincristine }\end{array}$ & Intravenous acyclovir \\
\hline [12] & 1 & Unilateral & $\begin{array}{l}\text { Cutaneous non-Hodgkin's } \\
\text { T-cell lymphoma }\end{array}$ & Chlorambucil and prednisone & Intravenous acyclovir \\
\hline [14] & 1 & Bilateral & Rheumatoid arthritis & Chlorambucil and prednisone & Intravenous acyclovir \\
\hline
\end{tabular}


Case Reports in

Ophthalmology
Case Rep Ophthalmol 2014;5:132-137

DOI: $10.1159 / 000362662$

Coisy et al.: Progressive Outer Retinal Necrosis and Immunosuppressive Therapy i

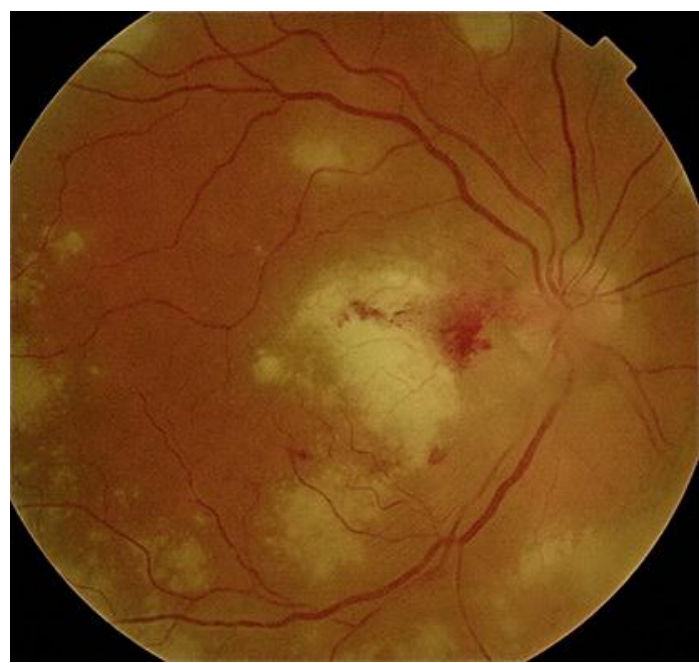

Fig. 1. Fundus appearance of the right eye showing multifocal retinal opacities and superficial retinal hemorrhages involving the posterior pole. There is an associated optic disc swelling and mild vitritis.

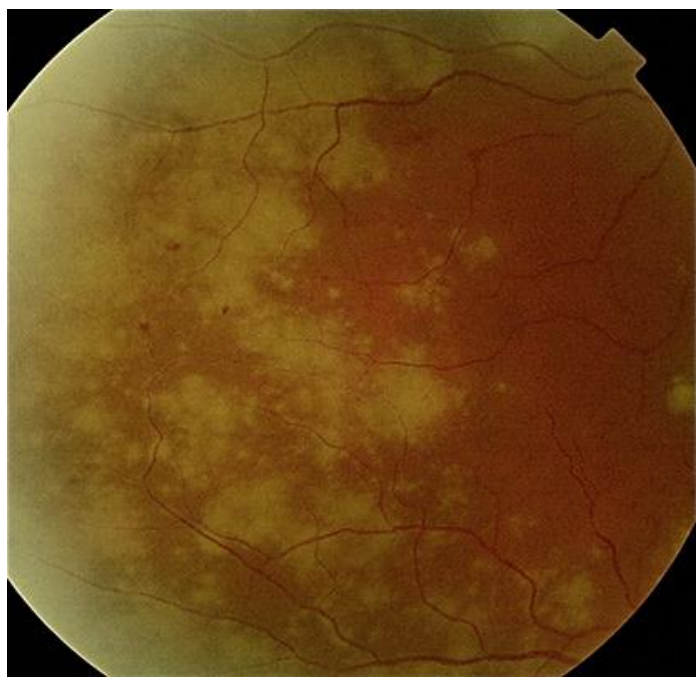

Fig. 2. Right retinal photograph showing multifocal and coalescent retinal opacities in the temporal retina. 